\title{
Analisis Kemampuan Keuangan Daerah dalam Mendukung Pembangunan Kota Palangka Raya
}

\author{
Pratiwi Subianto ${ }^{1}$, Irawan ${ }^{2}$ \\ 1pratiwi.subianto@upr.ac.id \\ 2irawan@feb.upr.ac.id \\ *Corres pondence author: pratiwi.subianto@ upr.ac.id; ;Tel.:+628XXXXXXXXXX
}

\begin{abstract}
This study uses statistical analysis and trends to see the development of the Degree of Fiscal Decentralization, Ratio of Regional Original Income to Total Regional Revenue, Degree of Fiscal Autonomy and Regional Fiscal Capacity of Palangka Raya City during the period 2008-2017 showing positive developments. Mean while, for the degree of Fiscal Decentralization, the Ratio between Tax and Non-Tax Revenue Sharing, the Contribution of Regional Assistance to Total Regional Revenue and Fiscal Needs for the City of Palangka Rayafor the period 2008-2017 showed negative results. This situation shows that the regional financial capacity of Palangka Raya City in supporting development independently tends to be lacking.
\end{abstract}

Keywords: Regional Financial Capability, Fiscal Decentralization, PAD

\begin{abstract}
Abstrak: Penelitian ini menggunakan analisis statistik dan trend untuk melihat perkembangan Derajat Des entralisasi Fiskal Rasio Pendapatan Asli Daerah terhadap Total PendapatanDaerah,DerajatOtonomi Fiskal dan Kapasitas Fiskal Daerah Kota Palangka Raya selama periode ta hun2008-2017menunjukkanperkembangan yang positif. Sedangkan untuk Derajat Des entralisasi Fiskal Rasio antara Bagi Hasil Pajak dan BukanPajak, Sumbangan Bantuan Daerah terhadap Total Pendapatan Daerah dan Kebutuhan Fiskal DaerahKota Palangka Raya periode tahun 2008-2017 menunj ukkan hasil nega tif. Kea daan ini memperlihatkan bahwakemampuan keuangan daerah Kota Palangka Rayada lam mendukung pembangunandenganmandiricenderungmasihkurang. Kata Kunci: Kemampuan Keuangan Daerah, Desensentralisasi Fiskal, PAD
\end{abstract}

\section{Pendahuluan}

Langkah pemerintah dalam upaya mempercepat pembangunan ekonomi daerah adalah dengan menerapkan otonomi daerah, melalui penyerahan kewenangan fiskal dari Pemerintah Pusat kepada Daerah (Desentralisasi Fiskal). Desentralisasi fiskal merupakan sarana yang dapat digunakan dalam rangka mempercepat terciptanya kesejahteraan masyarakat secara mandiri, Semangat Desentralisasi fiskal memberikan ruang kepada setiap daerah untuk menggali dan mengembangkan potensi keuangan daerahnya melalui regulasi dan kebijakan terkait dengan strategi peningkatan pendapatan daerah. Khusaini (2006) bahwa desentralisasi fiskal adalah implikasi langsung dari kewenangan/fungsi yang diserahkan kepada daerah yaitu menyangkut kebutuhan dana yang cukup besar, sehingga perlu diatur dan diupayakan perimbangan keuangan secara vertikal antara pusat dan daerah yang dimaksudkan untuk membiayai tugas yang menjadi tanggung jawabnya. Pola pengaturan hubungan antara pusat dan daerah yang semula bersifat sentralistik di masa Orde Baru yang diterjemahkan melalui Undang-Undang No 5 tahun 1974, kini telah dirubah dalam suatu pola hubungan yang lebih bersifat desentralisasi, melalui dasar hukum Undang-Undang No 22 Tahun 1999 mengenai kewenangan di pemerintah daerah, serta Undang-Undang No 25 Tahun 1999 mengenai Pembagian Keuangan antara pusat dan daerah. Yang diubah dengan Undang-Undang No 32 Tahun 2004 dan Undang-Undang No 33Tahun 2004.

Di Indonesia, pelaksanaan desentralisasi fiskal sebagai salah satu instrumen kebijakan pemerintah mempunyai prinsip dan tujuan antara lain (Mardiasmo, 2009): 1) Mengurangi kesenjangan fiskal antara pemerintah pusat dan pemerintah daerah (vertical fiskal imbalance) dan antar daerah (horizontal fiskal imbalance). 2) Meningkatkan kualitas pelayanan publik di daerah dan mengurangi kesenjangan pelayanan publik antar daerah. 3) Meningkatkan efisiensi peningkatkan sumber daya nasional. 4) Tata kelola, transparan, dan akuntabel dalam pelaksanaan kegiatan pengalokasian transfer ke daerah yang tepat sasaran. 
Undang-Undang No.33 Tahun 2004 tentang Perimbangan Keuangan menyatakan: Antara Pusat dan Daerah dilakukan dengan memberikan sumber- sumber pembiayaan yang jauh lebih besar kepada daerah. Implikasi langsung dari kewenangan/fungsi yang diserahkan kepada daerah adalah kebutuhan dana yang cukup besar. Untuk itu, perlu diatur perimbangan keuangan (hubungan keuangan) antara Pusat dan Daerah yang dimaksudkan untuk membiayai tugas yang menjadi tanggung jawabnya. Kebijaksanaan perimbangan keuangan antara Pusat dan Daerah dilakukan dengan mengikuti pembagian kewenangan atau money follow function. Hal ini berarti bahwa hubungan keuangan antara Pusat dan Daerah perlu diberikan pengaturan sedemikian rupa, sehingga kebutuhan pengeluaran yang akan menjadi tanggungjawab daerah dapat dibiayai dari sumber-sumber penerimaan yang ada (Sidik, 2002).

Derajat desentralisasi fiskal atau biasa disebut dengan derajat otonomi fiskal daerah merupakan aspek yang sangat penting dalam pelaksanaan otonomi daerah secara keseluruhan. Menurut hasil temuan Tim KKPFE UGM (dalam Hanafi dan Mugroho, 2009) untuk menentukan tolak ukur Derajat Desentralisasi Fiskal Daerah dapat dilihat dari Tabel berikut.

Tabel 1. Skala Interval Derajat Desentralisas Fiskal

\begin{tabular}{cc}
\hline PAD/TPD (\%) & Keterangan \\
\hline $0,00-10,00 \%$ & Sangat Kurang \\
\hline $10,01-20,00 \%$ & Kurang \\
\hline $20,01-30,00 \%$ & Sedang \\
\hline $30,01-40,00 \%$ & Cukup Baik \\
\hline $40,01-50,00 \%$ & Baik \\
\hline$>50 \%$ & Sangat Baik \\
\hline
\end{tabular}

Sumber: Hanafi dan Nugroho (2009)

\section{APBD dan pembangunan daerah}

Pengertian keuangan daerah sebagaimana dimuat dalam penjelasan Undang-Undang Nomor 32 Tahun 2004 tentang Pemerintahan Daerah adalah "Keuangan daerah adalah semua hak dan kewajiban daerah yang dapat dinilai dengan uang dan segala sesuatu berupa uang dan barang yang dapat dijadikan milik daerah yang berhubungan dengan pelaksanaan hak dan kewajiban tersebut".

Undang-Undang No. 17 Tahun 2003 tentang Keuangan Negara, menyebutkan bahwa APBD adalah rencana keuangan tahunan pemerintah daerah yang disetujui oleh Dewan Perwakilan Rakyat Daerah (DPRD). Namun dalam Peraturan Pemerintah No. 55 Tahun 2005 tentang Dana Perimbangan. APBD adalah rencana keuangan tahunan pemerintahan daerah yang dibahas dan disetujui bersama oleh Pemerintah Daerah dan DPRD, dan ditetapkan dengan peraturan daerah.

Pengertian APBD juga terdapat dalam PP No. 58 Tahun 2005 Pasal 20 tentang Pengelolaan Keuangan Daerah yang menyebutkan bahwa APBD merupakan satu kesatuan yang terdiri dari: (a) Pendapatan daerah, (b) Belanja daerah, dan (c) Pembiayaan daerah. Secara rinci ketiga hal tersebut akan diuraikan sebagai berikut:

a. Pendapatan Daerah

Pendapatan daerah adalah hak pemerintah daerah yang diakui sebagai penambah nilai kekayaan bersih dalam periode tahun bersangkutan (UU No. 33 Tahun 2004). Pendapatan daerah dalam struktur APBD dikelompokkan atas Pendapatan Asli Daerah (PAD), dana perimbangan, dan lain-lain pendapatan yang sah.

b. Belanja Daerah

Belanja daerah adalah semua kewajiban daerah yang diakui sebagai pengurang nilai kekayaan bersih dalam periode tahun anggaran yang bersangkutan. (UU No. 33 Tahun 2004).

c. Pembiayaan Daerah

Pembiayaan adalah setiap penerimaan yang perlu dibiayai kembali dan/atau pengeluaran yang akan diterima kembali, baik pada tahun anggaran yang bersangkutan maupun tahun- tahun anggaran berikutnya (UU No. 33 Tahun 2004).

Wamenkeu Suahasil Nazara pada East Java Economic Forum (EJAVEC) tahun 2020 meng atakan 
bahwa Anggaran Pendapatan dan Belanja Daerah (APBD) merupakan komponen yang sangat penting untuk dijalankan di seluruh Pemerintahan Daerah di Indonesia untuk mendorong percepatan perekonomian daerah.

Kota Palangka Raya merupakan daerah otonom yang diberikan wewenang fiskal dalam mengatur potensi sumber pendapatan yang ada di daerahnya. Pengelolaan sumber daya daerah menuntut efisiensi dan efektivitas, serta pertanggungjawaban yang transfaran kepada masyarakat. Adapun bentuk pertanggungjawaban pemerintah daerah Kota Palangkaraya dapat dilihat dari laporan keuangan pemerintah daerah sebagai salah satu alat untuk mengukur kinerja atau kemampuan daerah dalam mengelola keuangan daerahnya, hal ini dapat tercermin dari pendapatan asli daerah (PAD), semakin tinggi proporsi pendapatan asli daerah maka semakin baik kemandirian daerah tersebut dalam membiayai aktivitas pemerintahannya. Hal ini sejalan dengan penelitian Kusumayanti dan Triaryati, 2018 bahwa kemandirian pembangunan daerah akan terealisasi apabila pemerintah daerah meningkatkan kemampuan finansialnya dengan menggali sumber - sumber pendapatan daerah dan mengoptimalkan PAD sebagai sumber pembiayaan yang terbesar dalam penyelenggaraan pemerintahan dan pembangunan daerah. Berdasarkan data dari Badan Pengelola Pajak dan Retribusi Daerah Kota Palangka Raya, Pendapatan asli daerah (PAD) Kota Palangkaraya terdiri dari pajak hotel, pajak restoran, pajak hiburan, pajak reklame, pajak penerangan jalan umum, pajak parkir, pajak air tanah, pajak sarang burung wallet, pajak mineral bukan logam dan batuan, pajak bumi dan bangunan perdesaan dan perkotaan, bea perolehan hak atas tanah dan bangunan.

Tabel 2. Peraturan Daerah Tentang Pajak di Kota Palangka Raya, Kalimantan Tengah

\begin{tabular}{lcll}
\hline NO. & $\begin{array}{c}\text { NOMOR } \\
\text { PERDA }\end{array}$ & TAHUN & TENTANG \\
\hline 1. & 029 & 2002 & $\begin{array}{l}\text { Penerangan Jalan Umum dan Pajak Penggunaan } \\
\text { Tenaga Listrik }\end{array}$ \\
\hline 2. & 004 & 1998 & Pajak Hiburan \\
\hline 3. & 006 & 1998 & Pajak Hotel dan Restoran \\
\hline 4. & 001 & 1998 & $\begin{array}{l}\text { Pajak Pemanfaatan Air Bawah Tanah dan Air } \\
\text { Permukaan }\end{array}$ \\
\hline 5. & 005 & 1998 & Pajak Penerangan Jalan \\
\hline 6. & 006 & 2006 & Pajak Penerangan Jalan \\
\hline 7. & 002 & 1998 & $\begin{array}{l}\text { Pajak Pengambilan dan Pengolahan Bahan Galian } \\
\text { Golongan C }\end{array}$ \\
\hline 8. & 003 & 1998 & Pajak Reklame \\
\hline 9. & 019 & 2009 & Pajak Reklame \\
\hline
\end{tabular}

Pembiayaan pembangunan daerah masih sangat tergantung dari sumber pembiayaan pembangunan yang berasal dari pemerintah pusat. Rendahnya kemampuan daerah dalam menggali sumber-sumber pendapatan yang sah selama ini, selain disebabkan oleh faktor sumber daya manusia dan kelembagaan juga disebabkan oleh regulasi hukum. Pemberlakuan UU No. 25 Tahun 1999 yang kemudian diganti oleh UU No. 33 tentang Perimbangan Keuangan antara Pemerintah Pusat dan Daerah, dimana daerah mengalokasikan sebagian jenis-jenis pajak yang potensial bagi pemerintah pusat, merupakan salah satu faktor penyebab keterbatasan kemampuan daerah dalam menggali sumber-sumber penerimaannya. Oleh karenanya, Pemerintah pusat masih memiliki tanggung jawab untuk mendorong pembangunan disetiap daerah termasuk Kota Palangka Raya melalui kebijakan fiskal dalam bentuk transfer dana pusat ke daerah yang setiap tahunnya mengalami peningkatan. Hal ini terlihat dari tabel dibawah ini: 
Tabel 3. Perbandingan PAD dan Dana Perimbangan Kota Palangka Raya tahun 2008-2017

\begin{tabular}{ccccc}
\hline Tahun & $\begin{array}{c}\text { Pendapatan Asli } \\
\text { Daerah }\end{array}$ & $\begin{array}{c}\text { Dana } \\
\text { Perimbangan }\end{array}$ & $\begin{array}{c}\text { Total } \\
\text { Pendapatan } \\
\text { Daerah }\end{array}$ & $\begin{array}{c}\text { Total Belanja } \\
\text { Daerah }\end{array}$ \\
\hline 2008 & 24.599 .804 .198 & 400.369 .254 .512 & 424.969 .058 .710 & 524.734 .802 .315 \\
\hline 2009 & 22.535 .680 .868 & 410.807 .859 .890 & 433.343 .540 .758 & 533.737 .728 .525 \\
\hline 2010 & 26.197 .906 .649 & 504.419 .879 .253 & 530.617 .785 .902 & 533.100 .739 .434 \\
\hline 2011 & 34.973 .647 .041 & 466.395 .161 .314 & 501.368 .808 .355 & 604.674 .829 .127 \\
\hline 2012 & 50.515 .952 .309 & 552.429 .551 .513 & 602.945 .503 .822 & 701.107 .450 .180 \\
\hline 2013 & 62.816 .270 .444 & 638.529 .004 .050 & 701.345 .274 .494 & 849.852 .315 .965 \\
\hline 2014 & 88.001 .254 .976 & 689.110 .637 .755 & 777.111 .892 .731 & 947.894 .480 .390 \\
\hline 2015 & 122.314 .716 .629 & 707.089 .412 .100 & 829.404 .128 .729 & 1.048 .448 .764 .265 \\
\hline 2016 & 119.961 .089 .336 & 786.324 .243 .634 & 906.285 .332 .970 & 1.183 .609 .219 .568 \\
\hline 2017 & 150.925 .083 .031 & 841.752 .718 .011 & 992.677 .801 .042 & 1.100 .179 .027 .601 \\
\hline
\end{tabular}

Sumber: BPS dan BPKAD Kota Palangka Raya

Undang-Undang Nomor 33 Tahun 2004 tentang Perimbangan Keuangan Antara Pemerintah Pusat dan Pemerintah Daerah Pasal 1 PAD adalah penerimaan yang diperoleh daerah dari sumbersumber dalam wilayahnya sendiri yang dipungut berdasarkan peraturan daerah sesuai dengan peraturan perundang-undangan yang berlaku. Sedangkan menurut Mardiasmo (2004) PAD adalah penerimaan daerah dari sektor pajak daerah, retribusi daerah, hasil perusahaan milik daerah, hasil pengelolaan kekayaan daerah yang dipisahkan, dan lain-lain pendapatan asli daerah yang sah. Pengelolaan keuangan daerah menjadi instrumen yang sangat penting dalam penyelenggaraan otonomi daerah, utamanya dalam rangka melihat kinerja pengelolaannya dikaitkan dengan peningkatan kesejakteraan rakyat. Kinerja tersebut dapat dilihat dari proses penyusunan APBD, pelaksanaan dan penerapannya serta bagaimana pertanggung jawaban penggunaannya. Transparan merupakan prinsip keterbukaan yang memungkinkan masyarakat untuk mengetahui dan mendapatkan akses informasi seluas-luasnya tentang keuangan daerah. Bertanggung jawab merupakan perwujudan kewajiban seseorang atau satuan kerja untuk mempertanggung jawabnkan pengelolaan dan pengendalian sumber daya dan pelaksanaan kebijakan yang dipercayakan kepadanya dalam rangka pencapaian tujuan yang telah ditetapkan (Yuliastati K:2016). Gambaran mengenai kualitas rencana berbagai sektor pembangunan suatu daerah dapat dilihat dalam Anggaran pendapaian dan Belanja Daerah (APBD). Dengan melihat dan mencermati APBD akan terlihat apakah suatu sektor pembangunan mendapatkan skala prioritas. Melihat APBD dari satu tahun ke tahun berikutnya juga akan terlihat apakah pertumbuhan ekonomi semakin meningkat sejalan dengan pembangunan ekonomi tersebut. (Frahmawati BImulo:2009)

Menurut Musgrave (1991) dalam megukur kinerja keuangan daerah dapat digunakan derajat desentralisasi fiskal antara pemerintah pusat dan daerah. Selain itu, dalam melihat kinerja keuangan daerah dapat dipergunakan derajat kemandirian daerah untuk mengukur seberapa jauh penerimaan yang berasal dari daerah dalam memenuhi kebutuhan daerah.

Indikator yang digunakan untuk mengukut kemampua keuangan suatu daerah yaitu:

a. Derajat Desentralisasi Fiskal (DDF)

b. Derajat Otonomi Fiskal (DOF)

c. Kebutuhan Fiskal

d. Kapasitas Fiskal

Dari data di atas dana perimbangan dari tahun 2017 mengalami peningkatan sebesar 7\% dari tahun sebelumnya, dengan proporsi dana perimbangan sebesar $84,8 \%$ dan PAD hanya sebesar $15,2 \%$. Hal ini menunjukkan kemandirian fiskal Kota Palangka Raya masih rendah, merujuk pada penelitian Husain Jeddawi, M. (2021) mengatakan Indikator kemandirian fiskal yaitu proporsi dari PAD yang lebih besar daripada transfer dari Pusat, sebaliknya indikator daerah dikategorikan deficit kemandirian fiskal yaitu proporsi dari PAD yang lebih kecil daripada Transfer dari Pusat. Beberapa pemerintah daerah 
yang proporsi PAD nya lebih besar dari Transfer Pusat diantaranya adalah Kabupaten Bandung dan Provinsi Jawa Barat. Berdasarkan temuan diatas maka penulis mencoba meng analisis seberapa besar Kemandirian atau Kemampuan Keuangan Daerah dalam Mendukung Pembangunan Kota Palangka Raya.

\section{Metode}

Jenis penelitian yang dilakukan adalah pendekatan deskriptif-kuantitatif untuk mengetahui kemampuan keuangan daerah di Kota Palangka Raya yang ditinjau dari indikator Derajat Desentralisasi Fiskal, Derajat Otonomi Fiskal, Kapasitas Fiskal, dan Kebutuhan Fiskal dan mengetahui perkembangan Total Pendapatan Daerah, Pendapatan Asli Daerah, Dana Perimbangan dan Total Belanja Daerah. Tingkat kemampuan keuangan daerah Kota Palangka Raya diukur dengan menggunakan beberapa indikator kemampuan keuangan daerah yang terdiri dari:

a. Derajat Desentralisasi Fiskal (DDF) untuk mengukur Derajat Desentralisasi Fiskal antara Pemerintah Pusat dan Daerah digunakan formula sebagai berikut (Sukanto Reksohadiprojo, 2001).

$$
\begin{aligned}
& \text { DDF }=\frac{\text { Pendapatan Asli Daerah }(\mathrm{PAD})}{\text { Total Pendapatan Daerah }(\mathrm{TPD})} \times 100 \ldots \ldots \\
& \text { DDF }=\frac{\text { BagiHasilPajakBukanPajak }(\mathrm{BHPBP})}{\text { Total Pendapatan Da erah }(\mathrm{TPD})} \mathrm{X} 100 . \\
& \text { DDF }=\frac{\text { SumbanganBantuanDaerah (SBD) }}{\text { Total Pendapatan Daerah (TPD) }} \times 100 \ldots
\end{aligned}
$$

Dimana:

$\mathrm{TPD}=\mathrm{PAD}+\mathrm{BHPBP}+\mathrm{SBD}$

Tolak ukur Derajat Desentralisasi Fiskal Daerah dapat dilihat dari Tabel berikut:

Tabel 4. Skala Interval Derajat Desentralisas Fiskal

\begin{tabular}{cc}
\hline PAD/TPD (\%) & Keterangan \\
\hline $0,00-10,00 \%$ & Sangat Kurang \\
\hline $10,01-20,00 \%$ & Kurang \\
\hline $20,01-30,00 \%$ & Sedang \\
\hline $30,01-40,00 \%$ & Cukup Baik \\
\hline $40,01-50,00 \%$ & Baik \\
\hline$>50 \%$ & Sangat Baik \\
\hline
\end{tabular}

Sumber: Hanafi dan Nugroho (2009)

b. Derajat Otonomi Fiskal, Pengukuran Derajat Otonomi Fiskal menggunakan formula (Adrianus Dwi $S, 2008)$.

$$
\text { DOF }=\frac{\text { Pajak }+ \text { retribusi daerah }}{\text { Total Belanja Daerah }} X 100 \%
$$

Tabel 5. Skala Derajat Otonomi Daerah

\begin{tabular}{ll}
\hline \multicolumn{1}{c}{ Presentase } & \multicolumn{1}{c}{ Keterangan } \\
\hline $0-25 \%$ & Rendah Sekali \\
\hline $25-50 \%$ & Rendah \\
\hline $50-75 \%$ & Sedang \\
\hline $75-100 \%$ & Tinggi \\
\hline Sumber: Halim 2002 &
\end{tabular}


c. Kebutuhan Fiskal (Fiscal Need/KbF), Penghitungan Kebutuhan Fiskal suatu daerah dilakukan dengan formula (Sukanto Reksohadiprojo, 2001).

SKbF Kalteng $=\frac{\text { Jumlah Pengeluaran Kalteng/Jumlah Penduduk }}{\text { Jumlah Kab/Kota (Provinsi) }}$ X 100\%....... (6)

KbF Palangka Raya $=\frac{\text { PPP }}{\text { SKbF Kalteng }} \mathrm{X} 100 \%$

Dimana:

SkbF Kalteng = Rata-rata Kebutuhan Fiskal Standart se- Kalimantan Tengah

KbF Palangka Raya= Kebutuhan Fiskal Kota Palangka Raya

PPP = Jumlah Pengeluaran Rutin dan Pembangunan masing-masing daerah/pengeluaran aktual perkapita untuk jasa publik.

Semakin tinggi hasilnya, maka kebutuhan fiskal suatu daerah juga semakin besar. Semakin tinggi kebutuhan fiskal maka pengeluaran juga akan semakin meningkat.

d. Kapasitas Fiskal (Fiscal Capacity/ KaF), Kapasitas fiskal dapat dihitung dengan cara (Sukanto Reksohadiprojo, 2001).

SKaF Kalteng $=\frac{\text { PDRB Kalteng } / \text { Penduduk Kalteng }}{\text { Jumlah Kab } / \text { Kota (Provinsi) }}$ X 100\%

KaF Palangka Raya $=\frac{\text { PDRB } / \text { Penduduk Palangka Raya }}{\text { SKaF Kalteng }}$ X 100\%

Dimana:

SKaF Kalteng= Rata-rata Kapasitas Fiskal Standart se-Kalimantan Tengah

KaF Palangka Raya = Kapasitas Fiskal Kota Palangka Raya

Semakin tinggi hasilnya, maka kapasitas fiskal (daya tumbuh keuangan) suatu daerah semakin besar. Apabila kapasitas fiskal lebih besar dari kebutuhan fiskal maka potensi untuk mendapatkan pendapatan asli daerahnya cukup bagus tanpa harus ada bantuan dari pemerintah pusat.

Sedangkan untuk mengetahui perkembangan Derajat Desentralisasi Fiskal, Derajat Otonomi Fiskal, Kapasitas Fiskal dan Kebutuhan Fiskal menurut Suharyadi dan Purwanto,2012 dengan bentuk model sebagai berikut :

$Y=\alpha+b X$

$\alpha=\frac{\Sigma Y}{n}$

$\mathrm{b}=\frac{\sum \mathrm{XY}}{\sum \mathrm{X}^{2}}$

Dimana:

$\mathrm{Y}=$ Derajat Desentralisasi Fiskal atau Derajat Otonomi Fiskal atau Kapa sitas Fiskal Kebutuhan Fiskal

$\alpha=$ besarnya $Y$, saat $X=0$

$\mathrm{b}=$ besarnya $\mathrm{Y}$, jika $\mathrm{X}$ mengalami perubahan

$\mathrm{X}=$ waktu

$\mathrm{n}=$ Jumlah Data

Analisis trend ini digunakan untuk mengetahui perkembangan keuangan daerah dari tahun ke tahun. Dalam penelitian ini digunakan analisis trend dimana untuk melihat perkembangan Derajat 
Desentralisasi Fiskal, Derajat Otonomi Fiskal, Kapasitas Fiskal dan Kebutuhan Fiskal.

\section{Hasil dan Pembahasan}

\section{Perkembangan Pendapatan Asli Daerah Kota Palangka Raya}

Perkembangan Pendapatan Asli Daerah Kota Palangka Raya tahun 2008-2017 yang selalu meningkat setiap tahunnya terlihat dari Gambar 1. Jumlah perolehan Pendapatan Asli Daerah dipengaruhi oleh penerimaan seperti pajak daerah dan retribusi daerah.

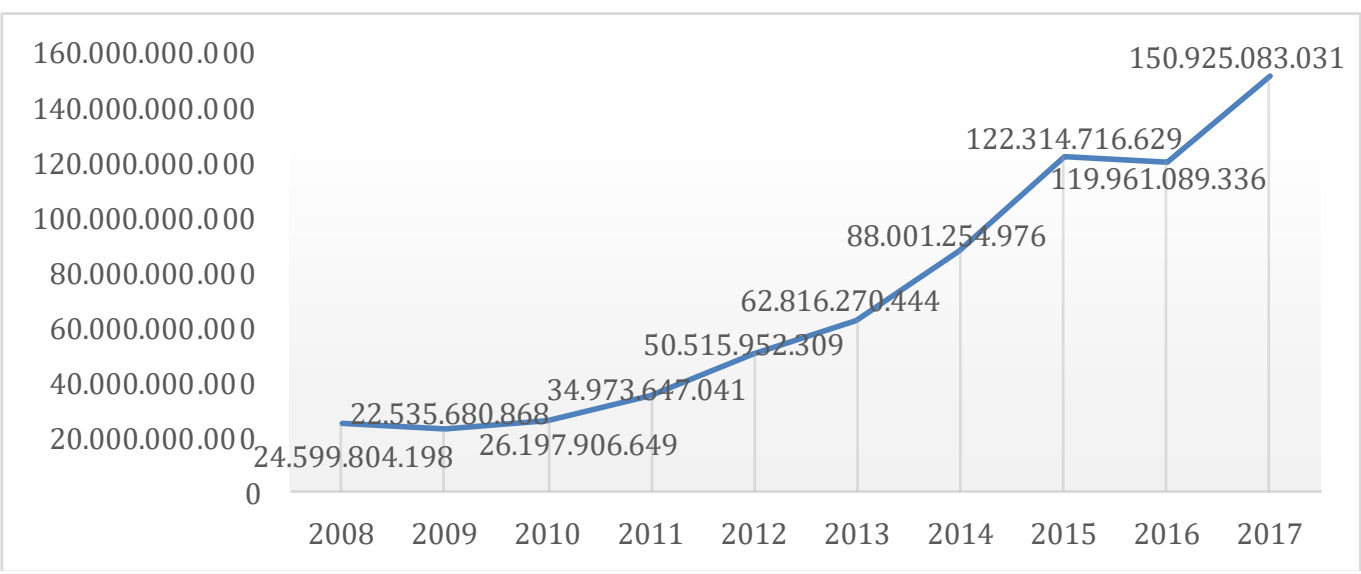

Gambar 1. PAD Kota Palangka Raya Tahun 2008-2017

Salah satu tolok ukur kemandirian pemda yang berkaitan dengan dana transfer membandingkan antara pendapatan asli daerah (PAD) dengan dana transfer (tanpa dana desa) yang diterima dari tahun ke tahun. Semakin besar peranan PAD semakin baik. Perkembangan proporsi PAD kabupaten/kota terhadap dana transfer (tanpa dana desa) tahun 2019 dan 2020 telihat dari gambar 2, menggambarkan terjadinya penurunan porsi PAD Kota Palangka Raya sebesar 4,99 persen, dari tahun 2019 sebesar 19,50 turun menjadi 14,51 pada tahun 2020.

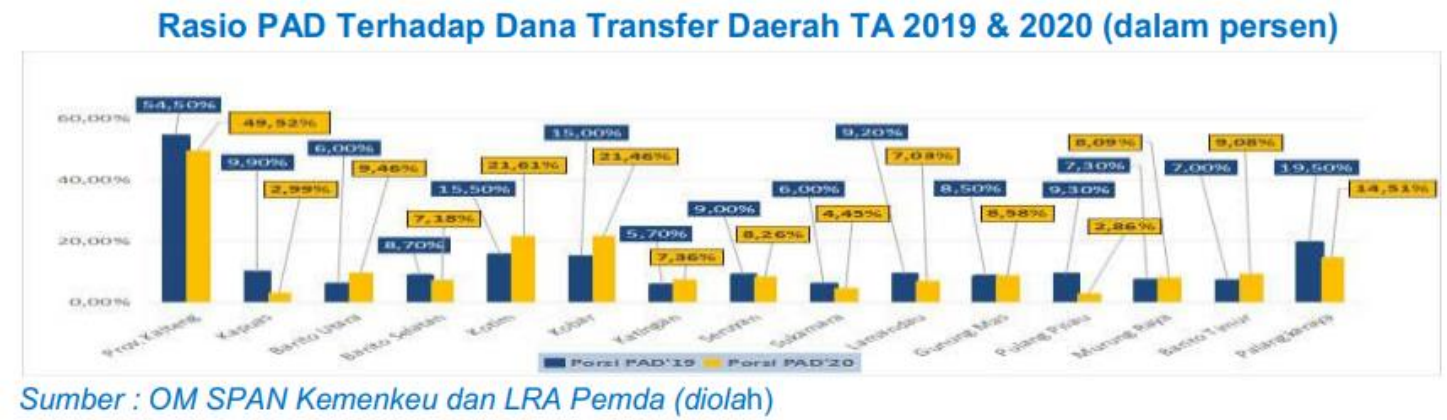

Gambar 2. Rasio PAD terhadap Dana Transfer Daerah TA 2019 -2020

\section{Analisis Kemampuan Keuangan Daerah Kota Palangka Raya}

a. Derajat Desentralisasi Fiskal

Dalam mengukur kinerja keuangan daerah dapat digunakan Derajat Desentralisasi Fiskal antar pemerintah pusat dan daerah. Perhitungan Derajat Desentralisasi Fiskal (DDF) dapat dilakukan dengan menggunakan 3 rumus, yakni rasio antara Pendapatan Asli Daerah (PAD)dengan Total Pendapatan Daerah (TPD), rasio Bagi Hasil Pajak dan Bukan Pajak (B HPBP) dengan Totap Pendapatan Daerah (TPD) dan rasio Sumbangan dan Bantuan Daerah (SBD) dengan Totap Pendapatan Daerah (TPD). 
Tabel 6. Derajat Desentralisasi Fiskal Kota Palangka Raya Tahun 2008-2017

\begin{tabular}{cccc}
\hline Tahun & PAD/TPD & DDF $(\%)$ \\
\hline 2008 & 5,7 & 6,6 & 87,5 \\
\hline 2009 & 5,2 & 7,4 & 87,3 \\
\hline 2010 & 4,9 & 13,1 & 69,1 \\
\hline 2011 & 6,9 & 8,0 & 84,9 \\
\hline 2012 & 8,3 & 10,1 & 81,4 \\
\hline 2013 & 8,9 & 7,8 & 83,1 \\
\hline 2014 & 11,3 & 7,3 & 81,2 \\
\hline 2015 & 14,7 & 5,5 & 79,6 \\
\hline 2016 & 13,2 & 5,1 & 81,6 \\
\hline 2017 & 15,2 & 4,3 & 71,2 \\
\hline Rata-rata & 10,4 & 7,1 & 79,9 \\
\hline
\end{tabular}

Sumber: Data Diolah, 2019

Hasil Derajat Desentralisasi Fiskal pada tabel tersebut menunjukkan bahwa rasio antara PAD terhadap TPD dari tahun 2008 sampai tahun 2010 mengalami penurunan, rasio antara Pendapatan Asli Daerah terhadap Total Pendapatan Daerah jika dilihat secara rata-rata rasio dari tahun 2008-2017 hasil rasionya adalah $10.4 \%$ (kategorinya sebagai alat ukur) yang menunjukkan bahwa kemampuan keuangan Kota Palangka Raya masih kurang dalam membiayai pembangunan daerah. Sedangkan Rasio Bagi Hasil Pajak dan Bukan Pajak (BHPBP) terhadap Total Pendapatan Daerah (TPD), menunjukkan secara rata-rata hasil rasio adalah $7,1 \%$. Adapun perhitungan rasio antara Sumbangan dan Bantuan Daerah (SBD) terhadap Total Pendapatan Daerah (TPD) secara rata-rata rasio dari tahun 2008-2017 hasil rasionya adalah 79,9\%. Hal ini menunjukkan kemandirian keuangan Kota Palangka Raya masih tergantung dari bantuan pemerintah pusat.

\section{b. Derajat Otonomi Fiskal}

Derajat Otonomi Fiskal Kota Palangka Raya menunjukkan kemampuan Pemerintah Daerah Kota Palangka Raya dalam membiayai sendiri penyelenggaraan pemerintahan, pembangunan dan pelayanan kepada masyarakat cenderung mengalami kenaikan setiap tahunnya.

Tabel 7. Derajat Otonomi Fiskal (DOF) Kota Palangka Raya Tahun 2008-2017

\begin{tabular}{cc}
\hline Tahun & Derajat Otonomi Fiskal (DOF) (\%) \\
\hline 2008 & 3,3 \\
\hline 2009 & 3,4 \\
\hline 2010 & 4,1 \\
\hline 2011 & 5,2 \\
\hline 2012 & 6,3 \\
\hline 2013 & 6,3 \\
\hline 2014 & 8,0 \\
\hline 2015 & 8,5 \\
\hline 2016 & 7,9 \\
\hline 2017 & 9,1 \\
\hline Rata-rata & 6,8
\end{tabular}

Sumber: Data Diolah, 2019

Jika dilihat secara rata-rata besarnya Derajat Otonomi Fiskal (DOF) Kota Palangka Raya adalah 6.8\%. Hal ini kemampuan Pemerintah Daerah Kota Palangka Raya dalam membiayai sendiri kegiatan penyelenggaraan pemerintahan, pembangunan dan pelayanan kepada masyarakat adalah sebesar $6,8 \%$ dari pajak dan retribusi daerahnya. 


\section{c. Kebutuhan Fiskal}

Kebutuhan fiskal mencerminkan kebutuhan pendanaan daerah untuk melaksanakan fungsi pelayanan dasar pemerintah daerah. Kebutuhan fiskal juga menunjukkan besarnya indeks pelayanan publik per kapita.

Tabel 8. Kebutuhan Fiskal Se-Provinsi Kalimantan Tengah dan Kota Palangk Raya Tahun 2008-2017

\begin{tabular}{ccc}
\hline Tahun & SKbF Kalteng (Rp) & KbF Palangka Raya (\%) \\
\hline 2008 & 42751,77 & 64,25 \\
\hline 2009 & 48135,41 & 55,16 \\
\hline 2010 & 47703,71 & 50,57 \\
\hline 2011 & 48410,25 & 55,59 \\
\hline 2012 & 73544,83 & 41,52 \\
\hline 2013 & 87722,47 & 39,62 \\
\hline 2014 & 94730,34 & 39,69 \\
\hline 2015 & 110002,28 & 36,67 \\
\hline 2016 & 88920,63 & 49,71 \\
\hline 2017 & 101083,12 & 39,48 \\
\hline Rata-rata & 75778,48 & 49,75 \\
\hline
\end{tabular}

Sumber: Data Diolah, 2019

*SKbF Kalteng: Rata-rata Kebutuhan Fiskal Standart se-Kalimantan Tengah

*KbF Palangka Raya: Kebutuhan Fiskal Kota Palangka Raya

Berdasarkan tabel di atas, pada tahun 2008-2017 kebutuhan fiskal standar se-Kalimantan Tengah adalah sebesar Rp.75,778.48; sedangkan kebutuhan fiskal Kota Palangka Raya yaitu sebesar 49.75\%. Kebutuhan fiskal yang semakin besar mengindikasikan pengeluaran semakin meningkat. Pada dasarnya kebutuhan fiskal adalah kebutuhan daerah untuk membiayai semua pengeluarannya dalam rangka menjalankan fungsi dan kewenangandaerah menyediakan pelayanan publik (expenditure needs).

\section{d. Kapasitas Fiskal}

Kemampuan pemerintah daerah untuk menghimpun pendapatan berdasarkan sumbersumberyang dimilikinya tercemin dari kapasitas fiskal daerahnya.

Tabel 9. Kapasitas Fiskal Se-Provinsi Kalimantan Tengah dan Kota Palangka Raya Tahun 2008-2017

\begin{tabular}{|c|c|c|}
\hline Tahun & SKaF Kalteng & KaF Palangka Raya (\%) \\
\hline 2008 & 1086,52 & 13,47 \\
\hline 2009 & 1214,01 & 12,73 \\
\hline 2010 & 1825,39 & 14,47 \\
\hline 2011 & 2091,94 & 14,21 \\
\hline 2012 & 2296,58 & 14,37 \\
\hline 2013 & 2454,80 & 14,39 \\
\hline 2014 & 2631,59 & 14,81 \\
\hline 2015 & 2864,64 & 15,16 \\
\hline 2016 & 3140,92 & 15,21 \\
\hline 2017 & 3459,35 & 15,22 \\
\hline Rata-rata & 2353,84 & 14,90 \\
\hline
\end{tabular}

Sumber: Data Diolah, 2019

*SKaF Kalteng: Rata-rata Kapasitas Fiskal Standart se-Kalimantan Tengah

*KaF Palangka Raya: Kapasitas Fiskal Kota Palangka Raya

Tabel di atas menunjukkan bahwa rata-rata kapasitas fiskal se-Kalimantan Tengah dari tahun 2008-2017 adalah Rp2,353.84. Sedangkan rata-rata kapasitas fiskal Kota Palangka Raya sebesar 
14.90\%. Hal ini menunjukkan bahwa jika dibandingkan antara kapasitas fiscal dan kebutuhan fiskalnya, Kota Palangka Raya memiliki kapasitas Fiskal yang lebih kecil yaitu $14.90 \%$ dibandingkan dengan kebutuhan fiskalnya sebesar $49.75 \%$, dengan kondisi tersebut artinya Kota Palangka Raya membutuhkan sumber fiskal dari luar (bantuan Pemerintah Pusat) untuk dapat memenuhi kebutuhan fiskalnya.

\section{e. Analisa Trend}

Analisis trend merupakan suatu pendekatan dengan menggunakan perbandingan keuangan baik pemerintah maupun perusahaan dari waktu ke waktu (misal dari tahun ke tahun). Jika trend baik maka dapat diasumsikan bahwa kinerja pemerintah atau perusahaan relatif baik dan begitu pula sebaliknya. Analisis ini merupakan analisis statistik dengan membandingkan data antar waktu, untuk melakukan suatu estimasi atau peramalan data yang sapa pada masa yang akan datang. Data dapat berupa nominal maupun rasio.

\section{Trend Perkembangan Derajat Desentralisasi Fiskal Rasio antara Pendapatan Asli Daerah terhadap Total Pendapatan Daerah Tahun 2008-2017}

Hasil Trend:

$$
\begin{aligned}
& \text { Nilai } a=\frac{\sum \mathrm{Y}}{\mathrm{n}} \text { Nilai } \mathrm{b}=\frac{\sum \mathrm{YX}}{\mathrm{X} 2} \\
& \begin{aligned}
a=\frac{94.3}{10} & \mathrm{~b}=\frac{59.15}{27.5} \\
=9.43 & =2.15
\end{aligned}
\end{aligned}
$$

Jadi persamaan trend $Y=9.43+2,15 x$ Merujuk pada grafik disamping Derajat Desentralisasi Fiskal rasio antara Pendapatan Asli Daerah terhadap Total Pendapatan Daerah mempunyai perkembangan yang positif.

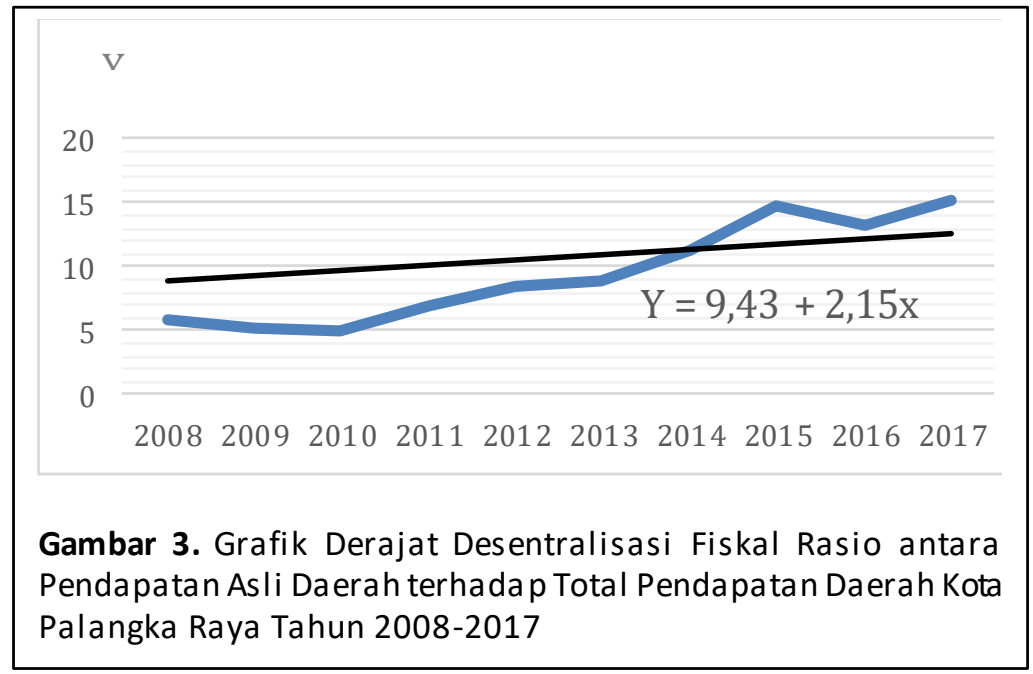

\section{Trend Perkembangan Derajat Desentralisasi Fiskal Rasio antara Bagi Hasil Pajak dan Bukan Pajak terhadap Total Pendapatan Daerah Tahun 2008-2017}

Hasil Trend:

$$
\begin{aligned}
& \text { Nilai } a=\frac{\sum \mathrm{Y}}{\mathrm{n}} \text { Nilai } \mathrm{b}=\frac{\sum \mathrm{YX}}{\mathrm{X} 2} \\
& \begin{aligned}
a=\frac{75.2}{10} & \mathrm{~b}=\frac{-26.63}{27.5} \\
=7.52 & =-0.96
\end{aligned}
\end{aligned}
$$

Jadi persamaan trend $Y=7.52-0.96 x$

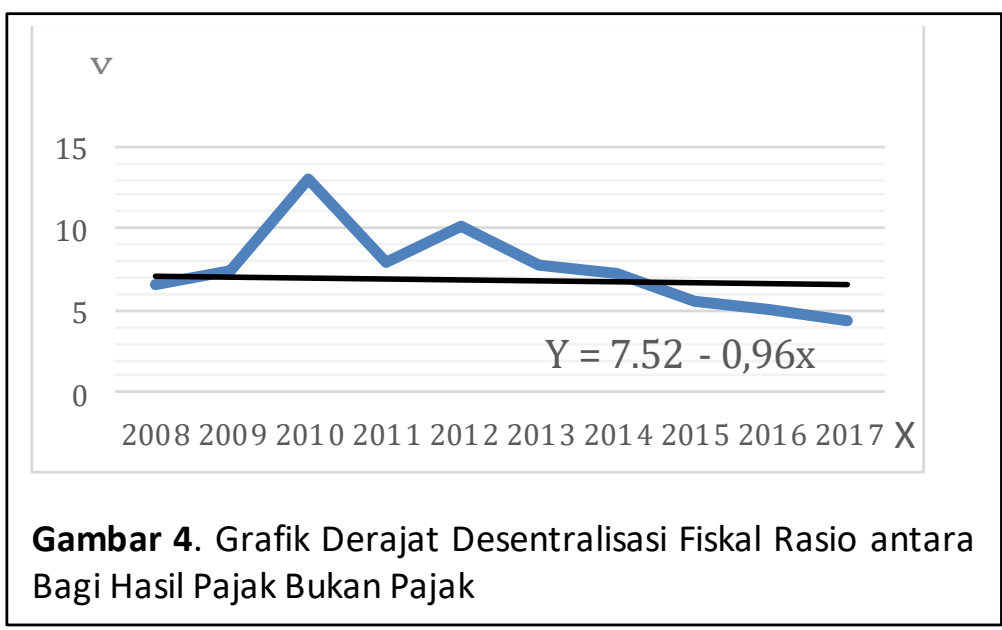


Hasil grafik diatas memperlihatkan kondisi bahwa kemampuan keuangan daerah Kota Palangka Raya ditinjau dari Derajat Desentralisasi Fiskal rasio antara Bagi Hasil Pajak dan Bukan Pajakterhadap Total Pendapatan Daerah mempunyai perkembangan yang negatif atau cenderung turun.

Trend Perkembangan Derajat Desentralisasi Fiskal Rasio antara Sumban gan dan Bantuan Daerah terhadap Total Pendapatan Daerah Tahun 2008-2017

Hasil Trend:

Nilai $a=\frac{\sum \mathrm{Y}}{\mathrm{n}}$ Nilai $\mathrm{b}=\frac{\sum \mathrm{YX}}{\mathrm{X} 2}$

$a=\frac{806.9}{10} \quad \mathrm{~b}=\frac{-39.25}{27.5}$

$=80.69=-1.42$

Jadi persamaan trend $Y=80.69-1.42 x$

Grafik menunjukkan perkembangan rasio Sumbangan dan Bantuan Daerah terhadap Total Pendapatan Daerah cenderung menurun

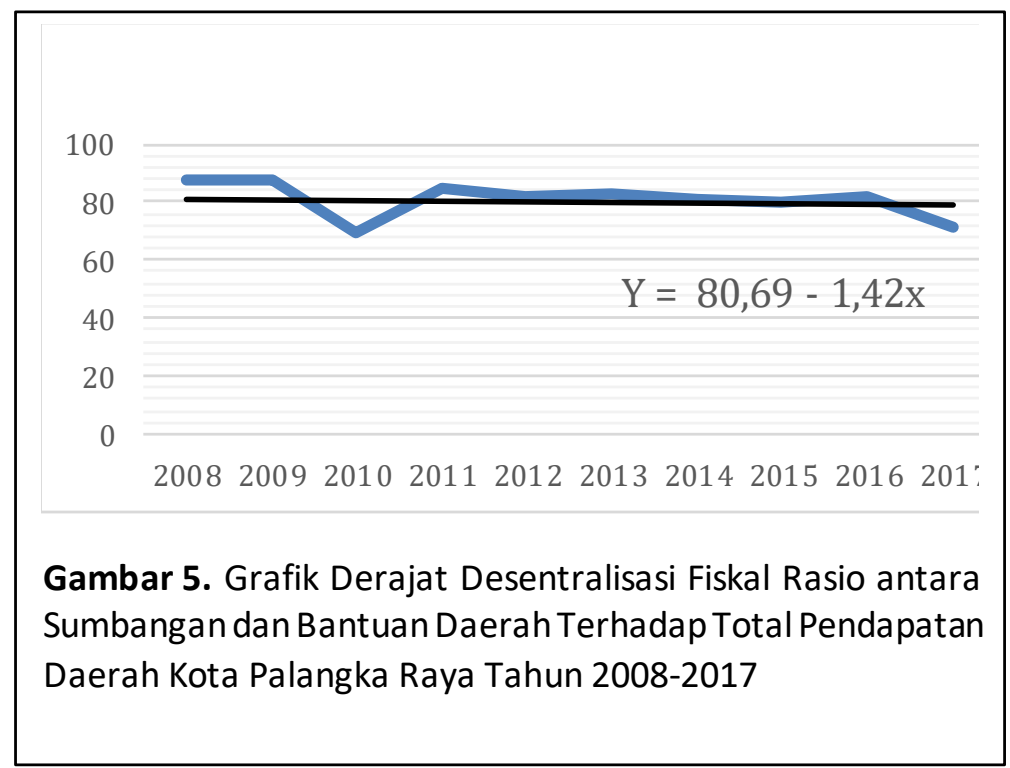

Grafik tersebut mengasumsikan bahwa jika terjadi penurunan terhadap sumbangan atau bantuan daerah maka berpengaruh pada keuangan daerahnya dimana transfer dari pemerintah pusat akan berkurang dan ketergantungan pemerintah daerah akan semakin berkurang.

\section{Trend Perkembangan Derajat Otonomi Fiskal Kota Palangka RayaTahun 2008-2017}

Nilai $a=\frac{\sum \mathrm{Y}}{\mathrm{n}}$ Nilai $\mathrm{b}=\frac{\sum \mathrm{YX}}{\mathrm{X} 2}$

$a=\frac{62.1}{10} \quad \mathrm{~b}=\frac{32.9}{27.5}$

$$
=6.21=1.19
$$

Jadi persamaan trend $Y=6.21+1.19 x$

Hasil grafik menunjukkan kemampuan keuangan daerah Kota Palangka Raya ditinjau dari Derajat Otonomi Fiskal mempunyai perkembangan yang positif

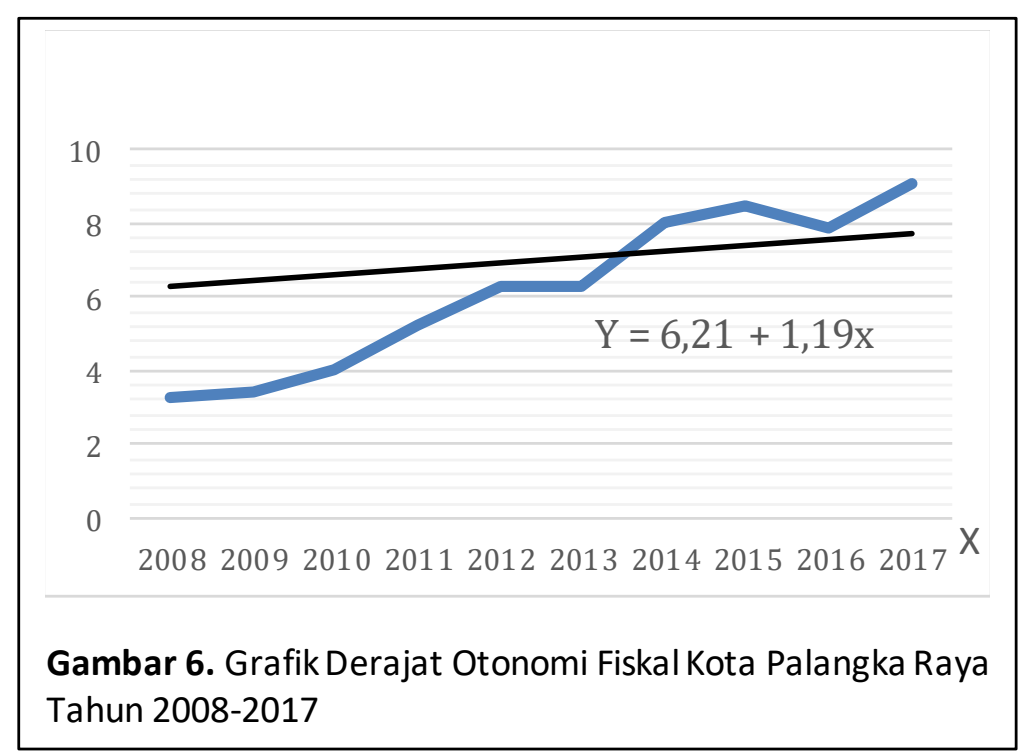




\section{Trend Perkembangan Kebutuhan Fiskal Kota Palangka Raya Tahun 2008-2017}

Hasil Trend:

$$
\begin{array}{ll}
\text { Nilai } a=\frac{\sum \mathrm{Y}}{\mathrm{n}} \text { Nilai } \mathrm{b} & =\frac{\sum \mathrm{YX}}{\mathrm{X} 2} \\
\begin{aligned}
a=\frac{472.26}{10} & \mathrm{~b} & =\frac{-113.525}{27.5} \\
=47.226 & & =-4.128
\end{aligned}
\end{array}
$$

Jadi persamaan trend $Y=47.226-4.128 x$

Grafik tersebut menunjukkan perkembangannya kemampuan keuangan daerah Kota Palangka Raya ditinjau dari Kebutuhan Fiskal mengalami fluktuasi dan ada kecendrungan mengalami penurunan

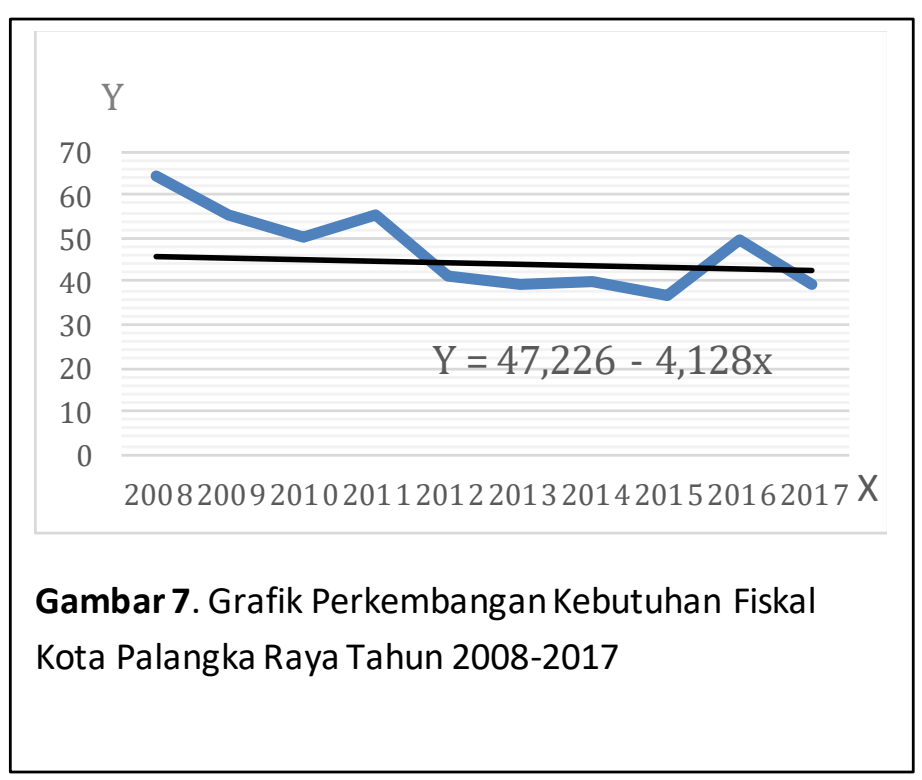

\section{Trend Perkembangan Kapasitas Fiskal Kota Palangka RayaTahun 2008-2017}

Hasil Trend:

Nilai $a=\frac{\sum \mathrm{Y}}{\mathrm{n}}$ Nilai $\mathrm{b}=\frac{\sum \mathrm{YX}}{\mathrm{X} 2}$

$$
\begin{array}{rlrl}
a & =\frac{144.04}{10} & b=\frac{10.98}{27.5} \\
& =14.404 & = & 0.39
\end{array}
$$

Jadi persamaan trend $\mathrm{Y}=14.404+0.39 \mathrm{x}$

Grafik terebut menunjukkan kemampuan keuangan daerah Kota Palangka Raya ditinjau dari Kebutuhan Fiskal mempunyai perkembangan yang positif

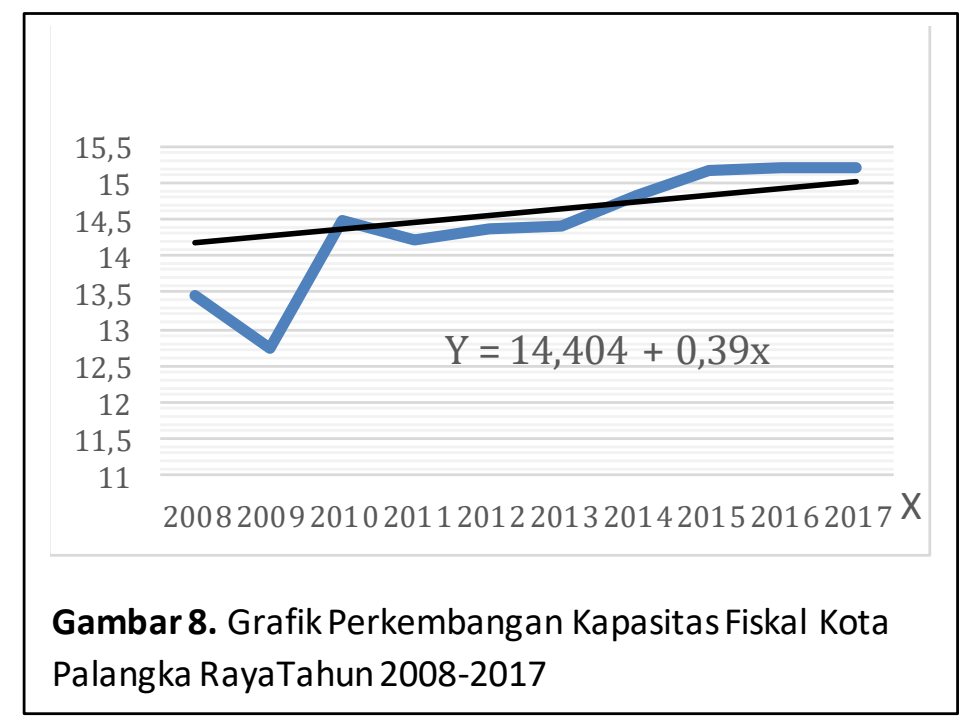

\section{Kesimpulan}

Berdasarkan analisa di atas memperlihatkan bahwa kemampuan keuangan daerah Kota Palangka Raya cenderung masih kurang. Oleh karenanya, perlu upaya peningkatan Pendapatan Asli Daerah Pemerintah Daerah Kota Palangka Raya dengan cara intensifikasi maupun ekstensifikasi, yakni dengan menggali potensi daerah yang ada, sehingga peluang-peluang baru untuk sumber penerimaan daerah Kota Palangka Raya.

\section{Daftar Rujukan}

Adrianus Dwi Siswanto. 2008. "Analisis Dampak Kebijakan Desentralisasi Fiskal terhadap Derajat Otonomi Pemerintahan Propinsi di Seluruh Indonesia."Jurnal Kajian Ekonomi dan Keuangan Vol. 12, No. 1 Maret 2008, 91- 117

Alexandro, Rinto. 2013. KEBIJAKAN PEMERINTAH PADA PERKEMBANGAN AGRIBISNIS DALAM PEMBANGUNAN EKONOMI DAERAH. JISPAR: Jurnal IImu Social, Politik dan Pemerintahan. Vol 2

No. 1 hal. 1-13. https://e-journal.upr.ac.id/index.php/JISPAR/article/view/353.

Alexandro, Rinto. 2020. Kontribusi Retribusi Daerah terhadap Pendapatan Asli Daerah (PAD) Kota 
Palangka Raya. Jurnal Penelitian dan Pengembangan Sains \& Humaniora. Vol 4 No. 2 hal.118-

125 https://ejournal.undiksha.ac.id/index.php/JPPSH/article/view/24747.

Blmulo, Frahmawati. "Peran APBD Terhadap Pertumbuhan Ekonomi Daerah."Jurnal Legalitas. Vol 2, No 1, 2009. Doi: Https://Doi.Org/10.33756/Jelta.V2i01.642

Hanafi, Imam Mugroho, Dan Tri Laksono. 2009. "Desentralisasi Fiskal: Kebijakan Perimbangan Keuangan Pemerintah Pusat Dan Daerah Di Indonesia." Malang: Ub Press.

Husain Jeddawi, M. 2021. "AlternatifStrategi Menekan Kesenjangan Kemandirian Fiskal Antar Daerah Di Indonesia." Jurnal Pallangga Praja (Jpp). 3, 2 (Nov. 2021), 51-57.

Kusumayanti, Ni Putu Ari.,Triaryati, Nyoman. 2018. "Analisis Potensi Sumber Pendapatan Asli Daerah (Pad) Pada Kabupaten Di Bali Di Luar Wilayah Sarbagita." E-Jurnal Manajemen Unud, Vol.7, No. 8, 2018: 4267-4296. Diakses Dari Doi:Https://Doi.Org/10.24843/Ejmunud.2018.V7.108.P9

Mardiasmo. 2004. "Otonomi dan Manajemen Keuangan Daerah." Yogyakarta: Andi.

Mardiasmo. 2009. "Akuntansi Sektor Publik." Yogyakarta: Andi Yogyakarta

Negara, Danes J dkk. 2020. "Studi Sumber dan Optimasi Pendapatan Asli Daerah Kota Palangka Raya." Bappedalitbang Kota Palangka Raya dan LPPM Univeritas Palangka Raya.

Reksohadiprodjo, Sukanto. 2001. "Ekonomika Publik." Yogyakarta: BPFE

Richard A. Musgrave \& Peggy B. Musgrave. 1980. "Public Finance in theory and Practice".edisi ke-3, McGraw Hill International Book Company. Tokyo.

Sidik, Machfud. 2002. Kebijakan, Implementasi Dan Pandangan Ke Depan Perimbangan Keuangan Pusat Dan Daerah, Direktur Jenderal Perimbangan Keuangan Pusat dan Daerah Departemen Keuangan RI Seminar Nasional "Menciptakan Good Governance demi Mendukung Otonomi Daerah dan Desentralisasi Fiskal" Yogyakarta, 20 April 2002.

Sidik, Machfud. 2002. Format Hubungan Keuangan Pemerintah Pusat Dan Daerah Yang Mengacu Pada Pencapaian Tujuan Nasional, Departemen Keuangan RI, Seminar Nasional "Public Sector Scorecard" Jakarta, 17-18 April 2002.

Suharyadi dan Purwanto. 2011. "Statistika untuk Ekonomi dan Keuangan Modern Edisi 2". Jakarta: Salemba Empat.

Supriyadi Supriyadi, Yanson I Nyalung, Abdul Djalil. 2020. Pengaruh Kepatuhan Wajib Pajak, Efektifitas Sistem, Perpajakan dan Pendapatan Terhadap Penerimaan Pajak Kendaraan Bermotor (Studi Kasus Di Kota Palangka Raya). Edunomics Journal Vol 1 No. 1 hal. 23-30. https://ejournal.upr.ac.id/index.php/edu/article/view/1595.

Kanwil Ditjen Pembendaharaan Provinsi Kalimantan Tengah. 2020. "Kajian Fiskal Regional Tahun 2020". Kementrian Keuangan Direktorat Jenderal Pembendaharaan.

Yuliastati, Yuliastati.2016."Urgensi Anggaran Pendapatan Belanja Daerah (APBD) Terhadap Perencanaan Pembangunan Daerah." Katalogis, vol. 4, no. 12 